\title{
信頼性理論の運航・整備計画への適用 *
}

\section{1. まえがき}

装置および機器などの集合体である機械システムに 対する整備は、これらのシステムが正常な機能を発揮 するように，また，故障を生じたときは故障による損 失を軽减する目的で行なわれている。機械システムに 対する整備は, 整備の量と回数を多くしても故障は必 ずしも減少するとは限らない。場合によっては, 整備 業務を過鄱に行なうことによって，逆に故障の多発が 見られることもある。したがって，機械システムに対 する整備では, 構成する装置および機器の個個の故障 特性に応じた適正な整備基準の設定を考える必要がで てくる.

機械システムの一つである航空機，鉄道車両および 船舶などの交通機関では, 交通あるいは輸送の安全と 確実が要求されるために, システムの故障発生ひん度 を少なくし運航計画の遂行をはかることが重要な命題 となっている。このため, 整備計画に対する要求はと くに強い，数年前までは交通機関に対する整備方策に は，過去の経験や蓄積やまたはそれによって養われた 直観や勘による個人の固有技術にたよった点が多か った。ところが，近年，各種技術の進展によって，故 障の発生のように問題が複雑では握し難い構造をもっ ていたり，または，過去の経験がた分でないときに， 可能なデータから包括した技術によって問題点を整理 しオペレーションズ・リサーチや信頼性理論などの 手法により解析する管理技術が著しい進歩をとげてき た。保守・整備もその例外ではなく新しいプログラム がつぎつぎに生まれている。しかしながら，船舶と いうシステムに対して，こうした管理技術の導入 は日が浅く，整備計画が十分に確立されている とはいい難い。米国海軍と二, 三の所で実施が みられる程度であるが, 今後は船舶の運航にと って必須の技術となろう。

ここでは，この方面の技術を早くから採り入 れている航空機と新幹線電車の整備方式を参考

\footnotetext{
*原稿受付 昭和 46 年 5 月 6 日

**正会員 鉄道技術研究所(東京都国分寺市光町 2-8-38)

***正会員船舶技術研究所 (東京都三鷹市新川 6-38-1)
}

曾爾 正夫**，玉木恕乎***

のためまず簡単に紹介し，ついで国鉄連絡船の例と米 国海軍における例とから，今後の船舶運航に適した整 備方策について考察を加えてみたい。

\section{2. 航空機の整備方式}

\section{1. 在来の整備方式}

航空機の整備は航空法の整備規定に基づいて行なわ れており，その性質によって随時整備と予防保守の二 つに分けられる。随時整備は機器が故障をしたら修理 をするという自然発生的な整備方式である。予防保守 は機器を常に最良な状態に維持しておこうとする予防 的な整備方式で, その装備品と機体構造に対して，い ままでの経験より表 1 に示すような使用時間限界を設 定して, 飛行時間がその時間に到達したら交換または 点検をするという計画整備の立場が採られている。

整備作業の区分を図 1 に示す。また，機体とェンジ ンを含む装備部品に対する通常作業の整備方式は図 2 の段階に割り当てて行なっている。ここで, シップ整 備とは航空機の機体での整備であり, ショップ整備と は工場での整備である。

航空機に対する整備は，これまでつぎのような考え 方に立っていた。すなわち, 装備品の故障の起こる確 率は計画整備を行なうことによって減少する。また， 定期的にオーバホールをすることによって装備品の信 頼度が上がると考えられていた。いま，上記の条件が 満足されるためには, 定期的に施行するオーバホール のときに装備品を新製品と同様な性能にしなければな らない。ところが, 使用されている装備品について故

表 1 航空機の整備限界時間 （単位: 時間）

\begin{tabular}{|c|c|c|c|c|c|c|c|c|}
\hline \multirow{3}{*}{\begin{tabular}{|cc} 
整 \\
機 \\
種 \\
類
\end{tabular}} & \multicolumn{4}{|c|}{ 運 航 整 備 } & \multirow{3}{*}{$\mid \begin{array}{c}\text { 整備 } \\
\text { 点定 } \\
\text { 時 }\end{array}$} & \multirow{3}{*}{$\begin{array}{l}\mathrm{D} \text { 整備 } \\
\text { ホ才機 } \\
\text { １：体 } \\
\text { ルバの }\end{array}$} & \multirow{3}{*}{$\begin{array}{c}\text { 形エ } \\
\text { y } \\
\vdots \\
y \\
\text { 式の }\end{array}$} & \multirow{3}{*}{$\begin{array}{l}\text { 整 } \\
\text { 備 } \\
\text { 時 } \\
\text { 間 }\end{array}$} \\
\hline & \multicolumn{2}{|c|}{$\mathrm{A}$ 整 } & 備 & \multirow{2}{*}{$\begin{array}{l}\mathrm{B} \\
\text { 整 } \\
\text { 備 }\end{array}$} & & & & \\
\hline & $\begin{array}{c}\mathrm{T} \\
\text { チェック }\end{array}$ & $\underset{夭 \text { チェク }}{\mathrm{E}}$ & $\underset{\text { チェック }}{\mathrm{P}}$ & & & & & \\
\hline & - & 12.5 & 25 & 80 & 300 & 4,000 & $R-2800$ & 2,000 \\
\hline $\begin{array}{l}\text { ダグラス } \\
\mathrm{DC}-8 \mathrm{C}\end{array}$ & - & 11.0 & 35 & 150 & 700 & 7,0000 & \begin{tabular}{|l}
$\mathrm{JT}-4 \mathrm{~A}$ \\
$\mathrm{JT}-3 \mathrm{D}$
\end{tabular} & $\begin{array}{l}5,000 \\
5,500\end{array}$ \\
\hline $\begin{array}{l}\text { ボーインク } \\
\text { B-727 }\end{array}$ & - & - & 25 & 150 & 800 & 7,000 & $\mathrm{JT}-8 \mathrm{D}$ & 3,500 \\
\hline
\end{tabular}




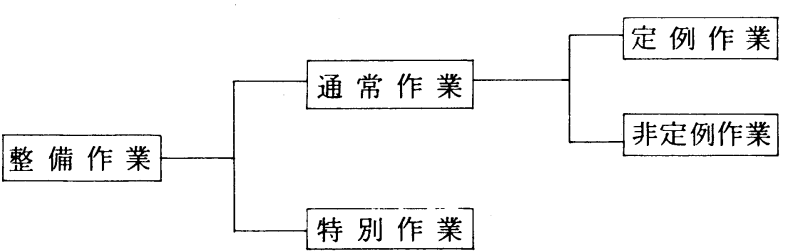

図 1 航空機の整備区分

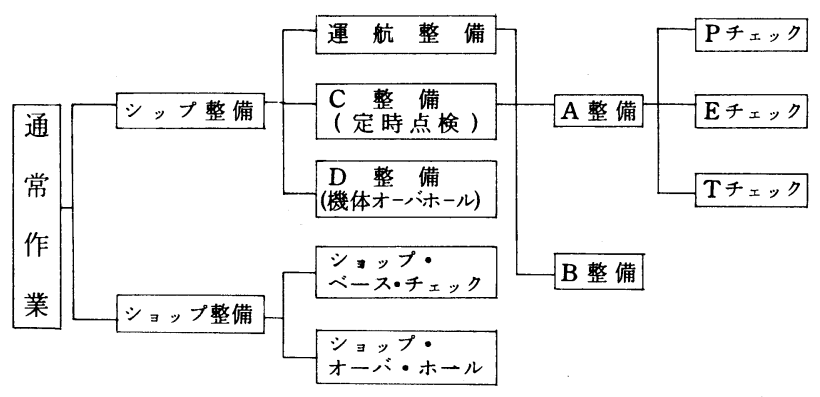

図 2 航空機の通常作業の整備方式

障データをもとに解析すると，上記の条件にかなうも のはほとんど存在せず, また，故障を防ぐ点でオーバ ホールが効果がないものもあることがわかった。この ように, 従来の定期的に施行するオーバホールは装備 品の故障管理に役立たないばかりでなく，せっかくな じみがでてきた装備品をも取りおろすという現象をも たらし，整備ひん度の増加と相まって逆に初期故障の はいり込む余地を与えてしまうという問題点を生じた. オーバホールは故障を防止し安全を確保するための手 段であると長い間信じられていたために，この固定観 念を打破ることは航空機事故からくる心理的要素とも 手伝って容易ではなかったといわれている。この考え 方を採り入れて，あるェンジンのオーバホール限界時 間は初期には 1,200 時間であったが, 6 年後には 12,000 時間に達している。

\section{2 航空機の新しい整備方式}

従来の整備方式の考え方の根幹は，装備品あるいは 構造部材は数多くの故障モードの集合体であるという ものであった．新しい整備方式はつぎのような考え方 に立っている。すなわち, 装備品や構造部材の故障に ついては，ただ一つの故障モードに起因することはな く, 数多くの故障モードをもっているので, 故障モ一 ドの型やその性質に基づいて, 故障モードごとに時間 と信頼度の関係を加味しながら整備をきめていこうと する考え方である。”このように，装備品や構造部材の そのときの状態に応じて必要なときにのみ整備すると
いうところが以前と異なる点である。ただ， 新しい整備方式への移行とともに，装備品と 構造部材に対する検査技術の開発が必要条件 となった。

表 2 故障モードの分類

\begin{tabular}{|l|c|c|}
\cline { 2 - 3 } \multicolumn{1}{c|}{} & $\begin{array}{l}\text { 故障の発生が } \\
\text { すぐ検出できる }\end{array}$ & $\begin{array}{c}\text { 故障の発生が } \\
\text { 検出できない }\end{array}$ \\
\hline $\begin{array}{l}\text { 時間－信頼性 } \\
\text { の関係あり }\end{array}$ & I & III \\
\hline $\begin{array}{l}\text { 時間ー信頼性 } \\
\text { の関係なし }\end{array}$ & II & IV \\
\hline
\end{tabular}

故障モードを大別すると表 2 のようになり それぞれに対する方策が立てられている。同 表のIのモードでは，強度が時間とともに低 下し, その状態が各種の検出器で検出できる から，未然に適切な処置を下すことができる. 現在, 一部の装備品については, 性能パラメ ータを地上のコンピュータで解析し，その装 備品について故障モードと強度の低下を監視 している．IIのモードに対する整備方式は，故障が時 間とは無関係に偶発的に発生するから，その発生を未 然に防止する方法は不可能である。このような故障モ 一ドに対しては，飛行中に故障が発生しても圥長など の手段が採り入れられているので，発生防止に努力す るのは当然であるが，むしろ，修理を迅速に行ないこ れが効果的である場合が多い。このため，不良筒所を 自動的に発見する装置の開発が進められている，III， IVの整備方式は, 故障の発生が時間と信頼度の関係に あるときとないときで, 故障が発生しても直ちに検出 されない，たとえば構造部材のき裂・腐食が発生した ときに対処するものである.これをそのまま放置すれ ば安全性に重大な影響を与える故障をひき起こすこと もありうる。このような故障モ一ドに対しては，整備 はあるひん度で点検し発見の機会を多くする必要があ る. 従来, この種構造部材の点検には, $\mathrm{X}$ 線, アイソ トープ，磁気探傷などの非破壊検査の方法が採り入れ られ，分解された部品の検査に対して実施されていた。 いまは，在姿のままで機体各部部材の点検ができるよ うな非破壊検査方法の開発が進められている.

以上のように, 従来の定期的に施行するオーバホー ルを廃止して, 装備品や構造部材の個個の故障モード に応じて，必要なときに必要な整備を行なうとする考 え方が航空機の新しい整備の方向である. 


\section{3. 東海道新幹線電車の整備方式}

\section{1 車両の保守管理システム}

車邽の保守管理システムは, 現場で発生した故障デ 一タを組織的に正しく集め，現場のシステムとそのサ ブシステムや機器と構造部材などの要内について故障 とそのモードを解析し，その特性に応じた最適な保守 方式を見出すことであり，その線戍を四 3 に示す。車 両整備の目的は，車両の安全の確保と車阿故障にとも なう生産性の低下防止である。これを信頼性の面から いいかえれば，車両の故障データを解析することによ って車両故障の単なる現象分析のみにとらわれず，内 蔵している「車両保守コスト」と「故障にともなう損 失」の合計額が最小になるように，最適保守管理時期 を見いだすことである。

保守管理を行なうためには，故障のデータからつぎ の項目について解析を行ない, 総合的な総断を下して いる.

(イ) 構成機器の信頼度

(ロ) 構成機器の故障にともなう損失の効果
(4) 構成機器のシステムに対する重要度

$\Leftrightarrow$ 予防保守投入人亡と保守効果

保守管理の基本的な方式はつぎのとおりである。

(1) 月単位処理……主として故障発生率に注月し，増 減の傾向または管理限界值との比較を行なってその 推移をは握している。

（2） 6 か月単位処理……過去 6 か月閆の情報からつぎ の解析を行なっている.

(イ) 信頼件のは握……機器別, 部留別に子防保守周 期内の故障を対象に，信頼度特性の解析を行ない 保守効果の確認を行なう。また，このデータをも とにシステム雷頼度の検討を行なうとともに重要 部品については新製後の信頼度調枯を行なう。

(口) 保守効果……定期保守人工と車洲故障の相関を 回㷌分析で解析する。

（大) 車両状態管理……新製後の経年別に分類した場 合の車両故障の分析調查。

（二）管理限界の修扯……故障獄より管理限界倠の修 正をを行なう。

(才) 最適な保守管理方式の設定……車両検修シミュ レーションなどにより最適な保 守管埋方式の設定を行なう。 現地からのこれらのデータは, 故 障報告と車両別使用状況の 2 項目 で，作業の簡略化をはかるととも に保守管理に必要なデータの解析 はすべてコンピュータにより行な っており，すみやかに現地にフィ ドバックして今後の車雨運用の資 料としている。

\section{2 新幹線電車の整備方式}

新幹線電車の整備方式は一定の 夙期で計䡆的に行なう定期検査を 主体とし，それに故障または大き な修䋹が発生しした場合の臨時検査 を維み合わせて行なっている。新 幹線電車の整備方式の区分と体系 を表 3 に示す。

国鉄における車両部品の予防保 守は，定期検査のときに全数交換 を行なう一般の予防保守方式によ らずに，整備を行なった時期で検 査基準に抵触する部分のみ加修を 行なう方式をとっている.なお， 新幹線電車の検査方式はさきの航 空機の場合と同様，あらゆる科学 
的計測体制の下で，全般検査を除き在姿の状態で検査 している.

車両管理システムの考え方をもとに，新幹線電車の 故障と検修歴を組み命わせて信頼度保守効果と故障影 響などについて解析を行なった結果，その概要はつぎ のとおりである

（1）定期検萳周期内に発生する故障と走行キ口の関係 をみると，走行キ口の增加にともなって故障率が増 大する摩耗故障パターンを示すものはきわめて少な く，初期故障パターンを六すものが多い現状である.

（2）運転中に発生:した故障による列車遅延は 1 件平均 4 分である。1 件当りの遅延時分は多重系となって いる主回路機器，ATCなどは少なく，一重系の部 分に高い結果がみられる。

（3）新幹線電車の機器別信頼度は予想以上に高い結果 がみられている。そのため，交番検査の周期を $20,000 \mathrm{~km}$ から $30,000 \mathrm{~km}$ に延長した場合の仕業 検䍒 $(1,200 \mathrm{~km}$ 鬧期) および臨時検查などにおける 加修率の推移をみると，父番検查の周期を 30,000 $\mathrm{km}$ に延長しても故陪発牛摔と加修件数はあまり変 らない結果がえられている。

以上のように信頼性:の管理技術を新幹線電車の運航 整備へ応用することによって, 検査期間の延長と検査 作業内容の削減が信頼度を落すことなく可能となり， これによって要期減や大幅な経費節減がえられた。

\section{4. 国鉄連絡船の整備方式}

\section{1 連絡船の保守管理システムと級別化}

船舶の整備体系は故洎による修理のほかに予防保守 があり，その範用はきわぬて公範明にわたる。これを 適正な修繥費でかつ效果的に保护整借を行なうことは なかなかむずかしい。

国鉄連絡船の整備体系は船舶安全法による定期と中 間の法的な検査工事と，国鉄としての自主的な検査工 事 (甲種中間工事) とにより予防保守の立場をとって いる。その体系を図 4 に示す。連絡船における整備の 目的と，保守管理システムに対する基本的な考え方は
新幹線電車の場合と全く同じである.

まず，検査工事を施行するにあたって特に重要なこ とは工事内容の決定である。その決定方法は船舶安全 法に定められた検査工事以外のものについては，いま までは過去の経験などによっていたので個人差による 影響が強かった。これをなくすため，機器の故障モー ドからその機器の機能, 重要度それに予防取替周期基 準を策定し, 連絡船の使用条件にあわせて機器の級別 を行ない, 検查工事内容を適正化する保守管理システ ムが行なわれるようになった。このような保守管理を 施行することによって, 整備業務の標準化, 修繥回帰 の延伸化が行なわれて修繥費の効果的な使用がはから れている。連絡船の検査は軽易な故障修理を除き外注 I.事を主体としているが, 現整備体系の中で航空機同 様科学的な計測体制を敷いている。

\section{2 適正な予防取替周期の決定}

連絡船では故障データをもとに，信頼性の考えを入 れて機器の予防取替周期の決定に経済性をも加えて検 堮している。たとえば然料弁の手入れ周期は，主機関 全部の燃料弁がどれも不具合にならない確率が大きい うちに手入れをしているが，これは連絡船の運行に支 障を与えないという考えからは望ましい。然料弁の予 防取替周期は A 社製機関ではこれまで750時間で手入 れをしており，機関製造者の取扱い基準でもそうなっ ていたが，運航実績からのデータにより，予防保守的 な控え目な見方でも，現状よりも約 100 時間手入れ周 期を延伸できることがわかった。図 5 は運航実績から えられた燃料弁寿命の確率密度分布であって, ヒスト グラムと機関 1 基の中で燃料弁が 1 個故障する確率を 示している。経済性から見孔ば，機関性能に異状をお よぼさない範囲でできるだけ使用したほうが使用時間 あたりのコストは安くなる。この図によれば，約 100 時間周期を延長しても故障件数の增加はまったく見ら れない．以上の観点から安全性をそこなわないで，も っとも保守効率がよいと思われる燃料弁の予防取替周 期は

$\mathrm{A}$ 社機関の場合 850 時間 $( \pm 50$ 時間)

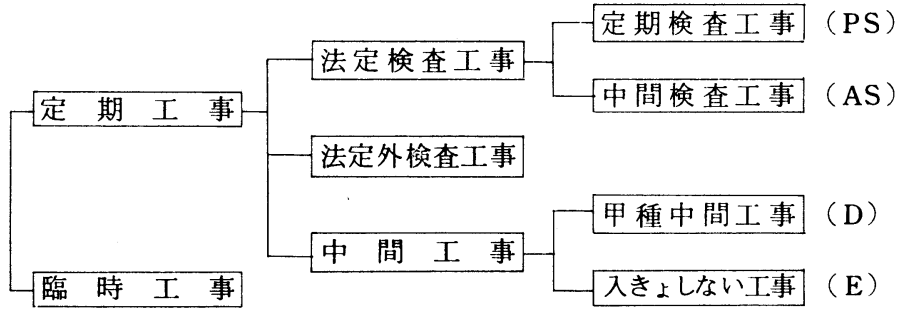

図 4 国鉄連絡船の整備体系
となる、また，然料弁の故障がわず か存在しても安全性はごく少ししか そこなわれないと考え，経済性の力 に重点をおけば，燃料弁使用時間に 対するコストは図 6 のようになり， 経費最小の時間を予防取替周期とす ることになる。この場合には

$\mathrm{A}$ 社機関の場合 $\quad 1,000$ 時間 となり，このときは機関 1 基につき 


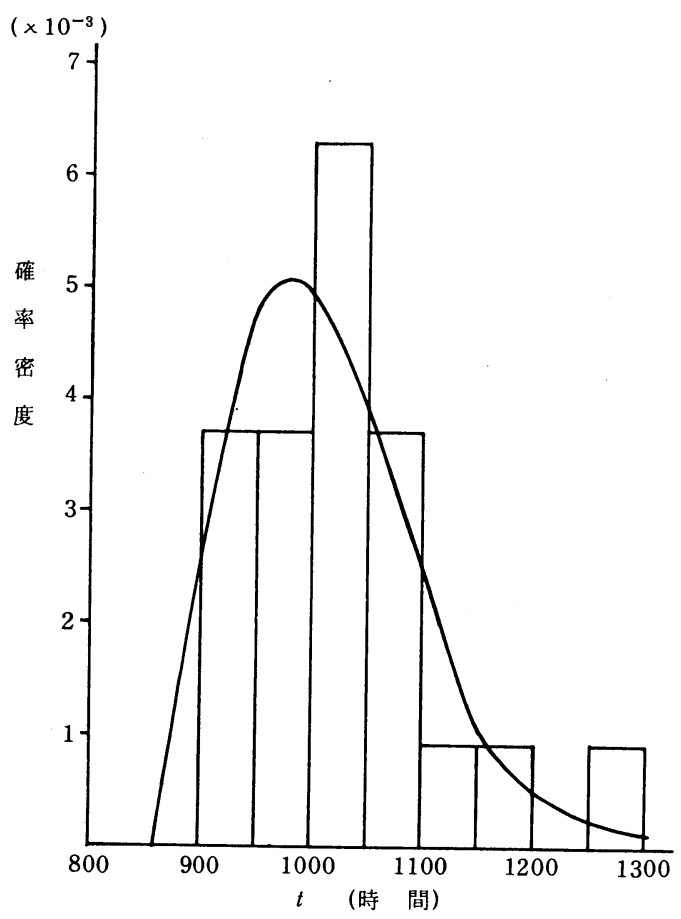

図 5 燃料弁の故障確率（A 社）

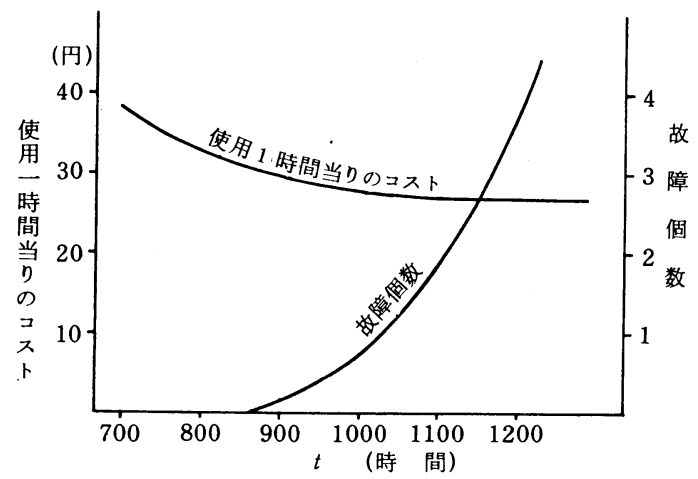

図 6 然料弁の故障率と時間当りのコスト（A 社）

燃料弁故障個数 0.676 個を許容している.

連絡船では現在，信頼性と経済性の両立する良好な 予防取替周期としてこの時間を基準にしている.

\section{3. 船舶資材の集中管理と適正在庫量の設定}

船舶と予備品との関係は船舶従事者にとっては切り 離すことのできないものである.

国鉄連絡船の予備品は 1 隻当りの品目数は約 7,000 点，数量にして約 30,000〜40,000 点におよぶもので あり，10 隻分を考えるとその数はおびただしいもの になる。

航海中, もし, 不測の事故を生じても応急措置によ
り港まで回航できれば修復は可能である。このために 予備品を各船に分散保有するむだの解消と資材事務の 合理化などから，船舶資材を陸上に集約化して物品を 集中管理する体制に最近変ってきた。また，物品の集 中管理体制の一環として，過去における使用実績と今 後の使用見通しとを十分検討のうえ, 各機器の適正在 庫量の設定をも実施している。

\section{5. その他の例}

信頼性理論を船舶の運航管理と整備へ適用している その他の例は米国海軍があげられる.米国海軍の所有 艦艇数は膨大な数にのぼり，艦艇の種類は多く，機関 の種類も原子力プラントから蒸気プラント, ガスター ビンプラント，ディーゼルプラントさらには複合プラ ントと多岐にわたっている。このような多数の艦艇の 機能を維持する保守整備の管理は, 科学的技術に裏付 けされた確立した体制によらねば到底不可能であると いわれている。これらの体制の詳細は軍用のため不明 なところが多いが, 断片的にはいくつかの報告がみら れる.それによれば，保守管理は運航の重要な機能の 一つであり，そのための機構と体制が確立され，数多 くのプログラムが開発されている。基本的な考え力は 効果分析によって整備効果をあげるよう整備閭期と内 容を決定する方法である。これには，海軍側の事情だ けでなくオーバホールを受持つ造船所側の能力的条件 もからむため，両者を含めた総合的な計画となってい る.このためには対象艦艇の使用時間を含む使命の限 定, システムの機能の限定, 整備効果測度 (評価関数) の決定, それにシステムの整備効果に対するモデル化 などが行なわれている。たとえば，駆逐艦用主機関に 対する年間運航使命時間を表 4 のように定め，これに 対する整備を計画している。

表 4 駆逐艦の年間運航計画例

\begin{tabular}{|c|c|}
\hline \multicolumn{1}{|c|}{ 運 航 状 態 } & 年間運航日数 \\
\hline 停 泊 気 蒸 & 10 日 \\
$20 ノ ッ ト$ 巡 航 & 25 \\
出力 $1 / 2$ 巡 航 & 23 \\
設計全力 (最高 4 時間連続) & 2 \\
\hline 計 & 60 日 \\
\hline
\end{tabular}

6. 運航整備計画に対する考察と結び

以上, 交通機関の運航整備計画に信頼性理論が適用 されている例をいくつかあげた．これらの中から船舶 の整備計画に関連する二, 三の問題点について述べ結 びとしたい。 
繰り返し述べたように，今後の整備に対する考え方 は定期的なオーバホールを繰り返すよりも，故障の原 因を除去して信頼性を上げるというように考方方が変 ってきており，それには故障の統計的特性の重要性が 大きくクローズアップされてきている。船舶の故障デ 一タに関しては本誌 1 月号に東大小泉先生の詳細な解 説があるのでそれを参照されたい。

また，この考え方をバックアップするものとして， 故障の検出とくに故障の自動診断と異常時の自動処理 がソフトウェア，ハードウェアともに重要な課題とな っている。

信頼性に対して製品の質とその整備は表裏の関係に あり，どちらが悪くても信頼度を上げることはできな い．たとえば，信頼性に対する考えがなくて作られた 船舶に対しては，作られてからどんなに整備をよくし ても信頼性の向上は望めない。したがって, 整備計画
整備効果をうんぬんする船舶は, 発注段階と製造段階 から信頼性に対する要求がなければならない。プラン トでいえば，性能として出力や熱効率 (燃料消費率) と並んで信頼度からさらにはアベイラビリティなど信 頼性に関する諸元の定量的な仕様が，船主と造船所と の間の契約にはいってくることが必要であろう．それ によって保守整備体制の確立が可能となろう.

$$
\text { 文献 }
$$

（1）青函船船鉄道管理局，「津軽丸形船舶機器の級別化分類表」

（2）日本国有鉄道，「区の検修作業への信頼性理論の応用」，研 究委員会報告書, 昭和 43 年 3 月

（3）日本国有鉄道，「編成電車の信頼性と合理的保守配分の研究 報告書 」, 昭和 43 年 3 月

（4）日本国有鉄道，「編成電車の信頼性と合理的保守配分の研究 報告書 」, 昭和 45 年 3 月

（5）小泉, 日本舶用機関学会誌，6巻 1号, p. 12 32（昭46-1） 